\title{
Využití aktivit podporujících profesní rozvoj a vnímání jejich překážek učiteli základních a středních škol ${ }^{1}$
}

\author{
StanisLaV MicheK
}

\begin{abstract}
Abstrakt: V souvislosti s výsledky mezinárodního šetrèni TALIS 2013, se snahou o zavedení kariérniho rádu a s dirrazem na profesni rozvoj pedagogických pracovniku nabývaji na významu otázky, jak se profesnè rozvijeji současni učitelé v ČR, jaké využivaji aktivity podporujici jejich profesni rozvoj a v čem vidi prekéžǩk svého profesního rozvoje. V príspèvku jsou prédstaveny výsledky dotaznikového šetreneni. Studie prezentuje rozdily u učitelì základnich a střednich škol $v$ preferenci aktivit podporujicich jejich profesni rozvoj v závislosti na typu školy, kde puisobi, genderu učitelì a délce pedagogické praxe. Jako nejvýznamnèjši prékážku uvádèli učitelé kolizi aktivit profesniho rozvoje se suým rozvrhem.
\end{abstract}

Klićcová slova: profesni rozvoj učitelì, prekeážky profesního rozvoje, učitelé.

Tato studie prezentuje výsledky výzkumu využití aktivit podporujících profesní rozvoj učitelů a některých překážek profesního rozvoje, který se uskutečnil $\mathrm{v}$ rámci prŕprav projektu Implementace kariérního systému (IMKA). Byl motivován snahou lépe porozumět tomu, jaké mají učitelé potřeby podpory profesního rozvoje, jak jsou informovaní o kariérním systému a jaké mají postoje $\mathrm{k}$ jeho návrhům. ${ }^{2}$

\section{Profesní rozvoj uČitelư A VÝZKUMY V ČR}

Rýdl (2014) hovoří o snahách o standardizaci profese učitele za posledních 20 let jako o nekonečném př́iběhu. Každá ze snah měla odlišnou politickou, finanční, odbornou a společenskou podporu. Každá byla velmi pravděpodobně motivována úsilím zlepšit vzdělávání dětí, žáků a studentů. Na pozadí tvorby standardu

\footnotetext{
$\overline{{ }^{1}}$ Tento článek vznikl v rámci projektu „Komparativní studie hodnocení a rozvíjení kvality výuky v odborných školách prostřednictvím hospitací" financovaného z grantu specifického výzkumu pedagogické fakulty UHK $\mathrm{v}$ roce 2016. Autor děkuje za poskytnutou podporu.

${ }^{2}$ Rozsah tohoto textu neumožňuje prezentovat výsledky celého dotazníkového šetření. Zaměřuje se proto pouze na odlišnosti v preferencích učitelů při profesním rozvoji a na odlišnosti ve vnímání překážek profesního rozvoje.
} 
učitele a kariérního systému šlo zřejmě aktérům snah vzdělávací politiky o „soubor aktivit vedoucích ke zdokonalování výkonu profese učitele a zkvalitňování výsledků učení žákü“, tedy o profesní rozvoj učitelů (Starý et al., 2012, s. 12).

Profesním rozvojem učitelů se $\mathrm{v}$ této studii rozumí v souladu $s$ publikací OECD (1998) širší vymezení než jen pouhé další vzdělávání učitelů. $\mathrm{V}$ publikaci OECD (2009, s. 49) je profesní rozvoj učitelů (dále PRU) vymezen široce „činnostmi, které rozvíjí dovednosti, znalosti, odbornosti a další charakteristiky jednotlivců jako učitele“. Na rozdíl od širšího vymezení PRU, jež uvádí Scheerens (2010, s. 19) a které zahrnuje př́pravné vzdělávání, uvádění učitelů, další vzdělávání a průběžný rozvoj učitelů ve škole, je o PRU $\mathrm{v}$ této studii hovořeno $\mathrm{z}$ hlediska času až po vstupu učitele do profese, tj. od okamžiku přijmutí ředitelem školy až po jeho uvolnění v důsledku penzionování.

Od doby, kdy Starý (Starý et al., 2012, s. 63-76) popisoval výzkumy PRU v České republice, tj. kriticky hodnotil limity šetření Factum Invenio (2009), pracoval $s$ výsledky studie McKinsey a kol. (2010), postrádal zapojení ČR do mezinárodního šetření OECD TALIS v roce 2007, došlo v oblasti poznání o PRU ke změnám. ČR se zapojila do šetření TALIS 2013, byly zveřejněny výsledky v národní zprávě (Kašparová et al., 2014a), v analytické zprávě (Kašparová et al., 2014b) a publikována zjištění o subjektivně vnímané zdatnosti učitelů v kontextu jejich profesního vzdělávání (Kašparová et al., 2015).
I přes tyto poznatky se však při plánování projektu IMKA na jaře 2015 v Národním institutu pro další vzdělávání (NIDV) objevil požadavek zjistit potřeby cílové skupiny projektu od kariérního systému a zájem učitelů o aktivity PRU. Požadavek byl iniciován „pravidly“ pro plánování projektu $\mathrm{v}$ rámci operačního programu „Výzkum, vývoj a vzdělávání“ a také snahou o uplatnění rozhodování založeného na důkazech (srov. Mareš, 2009).

\section{VÝZKUMNÉ OTÁZKY, METODY}

\subsection{Zacílení výzkumu}

Cílem výzkumu bylo přispět $\mathrm{k}$ současnému poznání $\mathrm{v}$ oblasti profesního rozvoje učitelů. Zaměření vycházelo $\mathrm{z}$ přesvědčení, že učitelé jsou při každodenní práci konfrontováni $s$ velmi pestrou nabídkou aktivit, prostřednictvím kterých se mohou rozvíjet. Oproti šetření TALIS z roku 2013 byla rozšířena skupina respondentů o učitele MŠ, 1. stupně ŽS, gymnázií, SOŠ, SOU, VOŠ a ZUŠ. Podobně byla rozšířena nabídka aktivit. V souladu se závěry Gareta a kol. (2001) byl kladen důraz na intenzivnější formy PRU zahrnující prvky aktivního učení, spolupráci s jinými učiteli, aktivity trvající delší časové období, príp. diferencované podle individuálních potřeb jednotlivých učitelů.

V tomto textu jsou potom hledány odpovědi na výzkumné otázky:

Jak se liší zájem učitelů o aktivity profesního rozvoje v závislosti druhu a typu školy a dalších proměnných (gender, délka pedagogické praxe, nejvy̌̌ší dosažené vzdělání)? 
Jak se liší učitelé ve vnímání překážek profesního rozvoje v závislosti na druhu a typu školy a dalších proměnných (gender, věk)?

Cílem studie je představit podstatná zjištění ve využívání aktivit podporujících PRU a vnímání překážek PRU učiteli základních a středních škol.

\subsection{Sběr dat}

Při konstrukci dotazníkových položek se vycházelo z již uskutečněných výzkumných šetření (výzkum OECD TALIS 2013, dotazníkové šetření NIDV z dubna 2015 zjištujúí́ informovanost a postoje ředitelů škol ke kariérnímu systému uskutečněné v rámci př́prav projektu IMKA). Dalším zdrojem informací pro tvorbu dotazníku byla ohnisková skupina věnující se podpoře a aktivitám přispívajícím $\mathrm{k}$ PRU uskutečněná v květnu 2015. Cílem ohniskové skupiny se zkušenými učiteli bylo zjistit, jaké aktivity a za jakých okolností doporučují k PRU. Dále nabídla vhled do uvažování učitelů o kariérním systému, tj. rozšírila poznatky ke 2. a 3. části dotazníku. Následně byla podoba dotazníku konzultována se dvěma výzkumníky, kteří dali podněty $\mathrm{k}$ vylepšení první části dotazníku. Po jazykové korektuře byl výsledný dotazník tvořen z těchto čtyř částí: a) podpora profesního rozvoje učitelů, b) informovanost o kariérním systému, c) očekávání, překážky a potenciál kariérního systému, d) sociodemografické otázky.
V první části dotazníku ${ }^{3}$ byl pro respondenty ústřední pojem profesní rozvoj učitelu charakterizován jako „soubor činností vedoucích ke zdokonalování výkonu profese učitele a zkvalitňování výsledků učení žáků". V této části respondenti uváděli u 32 aktivit profesního rozvoje učitelů rožrazených do tematických oblastí pomocí dichotomické škály (ano/ne), zdali využili v posledních 12 měsících nabízenou aktivitu (znění položek je uvedeno $\mathrm{v}$ tabulce A v príloze). Jednalo se o těchto sedm oblastí s uvedením počtu položek v závorce:

1. aktivity založené na vzdělávání (3);

2. aktivity napomáhající PRU založené na pozorování a následném hodnocení (4);

3. podpora od kolegů, prípadně od souvisejících profesí (6);

4. aktivity založené na sebe/hodnocení (5);

5. formy podporující PRU (6);

6. návštěvy jiných organizací (4);

7. studium a metodická podpora (4).

Dále u 1., 4., 6. a 7. oblasti uváděli respondenti pro 16 položek hodnocených opět pomocí dichotomické škály, zdali se plánují v následujících 12 měsících zúčastnit nabízené aktivity. U 2.-5. oblasti u 21 aktivit posuzovali, jestli postrádají konkrétní aktivitu ke svému rozvoji. Následně respondenti posuzovali sedm položek charakterizujících překážky PRU. Jednalo se o shodné položky jako $\mathrm{v}$ šetření TALIS 2013, při použití škály: rozhodně nesouhlasím - nesouhlasím - souhlasím - rozhodně souhlasím. Respondenti také mohli doplnit pomocí dvou otevřených otázek jinou nenabízenou aktivitu či překážku PRU.

${ }_{3}^{3}$ Vzhledem k zaměření studie je popsána pouze první část dotazníku věnující se PRU. 
Tab. 1. Složení souboru respondentů-učitelů

\begin{tabular}{|c|c|c|c|c|}
\hline \multicolumn{2}{|l|}{ Učitelé ČR } & $\begin{array}{c}\text { Počet } \\
\text { respondentů }\end{array}$ & \begin{tabular}{|c|c|}
$\begin{array}{c}\text { Podíl učitelů } \\
\text { v dotazníkovém } \\
\text { šetření }(\%)\end{array}$ \\
\end{tabular} & $\begin{array}{l}\text { Podíl učitelı̊ } \\
\text { v ČR } \mathbf{R}^{4}(\%)\end{array}$ \\
\hline \multirow{2}{*}{ Pohlaví } & muž & 472 & 19,1 & 19,1 \\
\hline & žena & 1970 & 79,7 & 79,9 \\
\hline \multirow{2}{*}{$\begin{array}{l}\text { Kvalifikova- } \\
\text { nost pro čin- } \\
\text { nost učitele }\end{array}$} & kvalifikovaný & 2334 & 94,4 & 91,6 \\
\hline & nekvalifikovaný & 70 & 2,9 & 8,4 \\
\hline \multirow{6}{*}{$\begin{array}{l}\text { Nejvy̌šsí } \\
\text { dosažené } \\
\text { vzdělání }\end{array}$} & střední vzdělání s výučním listem & 3 & 0,1 & 1,2 \\
\hline & $\begin{array}{l}\text { střední vzdělání s maturitní } \\
\text { zkouškou }\end{array}$ & 234 & 9,5 & 26,6 \\
\hline & $\begin{array}{l}\text { vyšší odborné vzdělání (včetně } \\
\text { konzervatoří) }\end{array}$ & 56 & 2,3 & 2,4 \\
\hline & bakalářské vzdělání & 150 & 6,1 & \multirow{3}{*}{69,9} \\
\hline & magisterské vzdělání & 1838 & 74,4 & \\
\hline & doktorský studijní program & 155 & 6,3 & \\
\hline \multirow{11}{*}{ Typ školy } & $\mathrm{MŠ}$ & 389 & 15,7 & 18,7 \\
\hline & 1. stupeň ZŠ & 216 & 8,7 & 21,4 \\
\hline & 2. stupeň ŽS & 255 & 10,3 & 21,0 \\
\hline & nižší stupeň víceletého gymnázia & 50 & 2,0 & 4,6 \\
\hline & střední školy & 1115 & 45,1 & 23,7 \\
\hline & gymnázia & 337 & 13,6 & 3,8 \\
\hline & SOŠ & 523 & 21,2 & 10,0 \\
\hline & SOU & 89 & 3,6 & 9,9 \\
\hline & VOŠ & 26 & 1,0 & 2,6 \\
\hline & konzervatoře & 7 & 0,3 & 1,0 \\
\hline & ZUŠ & 55 & 2,2 & 6,7 \\
\hline
\end{tabular}

\section{Administrace DotaZníkU}

\section{A SOUBOR RESPONDENTU゚}

9. června 2015 bylo vedením NIDV emailem osloveno 14852 učitelů s prosbou o vyplnění dotazníku v elektronické formě v prostředí Google Documents. K oslovení byly záměrně vybrány emaily z databáze NIDV čítající 81173 kontaktů učitelů, kteří se za dobu existence institutu účastnili aktivit dalšího vzdělávání pedagogických pracovníků pořádaného

\footnotetext{
${ }^{4}$ Počet učitelů v ČR byl čerpán ze Statistické ročenky školství 2014/2015 - výkonové ukazatele (http://toiler. uiv.cz/rocenka/rocenka.asp).
} 
NIDV. Byly vybrány takové emaily, aby struktura oslovených učitelů odpovídala struktuře počtu učitelů rozřazených dle typů a druhů škol v ČR. Pro daný typ školy po stanovení kvóty byl při výběru použit náhodný výběr emailů. Z 14852 mailů jich 757 nebylo doručeno.

Do výzkumu se zapojilo 2472 učitelů ze všech krajů ČR, všech typů a druhů škol regionálního školství. Jednalo se o 16,7\% návratnost od oslovených, kteří uvedli alespoň některý ze sociodemografických údajů. Složení souboru respondentů-učitelů je uvedeno v tabulce 1 .

$\mathrm{Z}$ hlediska genderu odpovídá struktura respondentů struktuře učitelů v ČR. Dotazník vyplnil vyšší podíl kvalifikovanějších učitelů, kteří měli nejvyšší dosažené vzdělání vyšší pro př́íslušný typ školy, než je běžné v ČR. Zúčastnili se ho učitelé ze všech krajů ČR. Struktura souboru respondentů $\mathrm{z}$ hlediska typu školy se liší oproti struktuře učitelů v ČR. Věková struktura respondentů $\mathrm{v}$ souhrnu i podle typů škol spíše odpovídá věkové struktuře učitelů v ČR.

Pro nalezení odpovědí na výzkumné otázky bude zaměřena pozornost pouze na učitele ISCED 1-3, kterým nejlépe odpovídá znění položek dotazníku. Výsledky výzkumu vychází z dat od respondentů, kteři jednoznačně uvedli, 5 že působí na 1. stupni $Z \check{S}, 2$. stupni $Z S ̌$, gymnáziu, SOŠ a SOU. Tímto došlo k zúžení datové základny na 1420 respondentů.

\section{STATISTICKÉ POSTUPY A FORMA PREZENTACE VÝSLEDKU゚}

Zájem učitelů o aktivity podporující PRU byl zjištován pomocí otázek, zda učitelé v uplynulém roce uskutečnili aktivitu PRU - podíl kladných odpovědí je uveden $\mathrm{v}$ tabulce $\mathrm{A} \mathrm{v}$ príloze. $\mathrm{S}$ ohledem na první výzkumnou otázku byly testovány odlišnosti dle délky praxe, genderu, nejvyššího dosaženého vzdělání učitelů a typu školy, na níž působí. Statisticky významné rozdíly byly zjištovány pomocí testu nezávislosti chí-kvadrátu. Pro zjištění těsnosti vztahu mezi nezávislými proměnnými a uskutečněním aktivit PRU byly použity míry asociace: koeficient fí (pro tabulky $2 \times 2)$ a Cramerovo V.

U sedmi položek charakterizujících překážky PRU byla nejprve použita explorační faktorová analýza $s$ cílem nalézt latentní proměnné. Ta však společně $s$ kontrolou vnitřní konzistence potenciálních faktorů neposkytla statisticky uspokojující výsledky. Proto byla zamítnuta úvaha o vytvoření součtových indexů a položky charakterizující překážky PRU byly následně analyzovány individuálně.

U položek charakterizujících překážky PRU bylo zkoumáno, zda se jedná o normální rozdělení. Výsledky Kolmogorovova-Smirnovova testu hodnoty špičatosti a šikmosti ukázaly, že diference mezi daty a teoretickým normálním rozdělením jsou větší, než abychom je mohli připsat náhodě $(\mathrm{p}<0,05)$. Na druhou stranu se

\footnotetext{
${ }_{5}^{5}$ Respondenti, kteří uvedli více než jeden typ školy, kdy působí např. na 1. i 2. stupni ZŠ, nebo na SOU a SOŠ, nejsou zahrnuti do následujících zjištění.
} 
jednalo o velký výběr, kdy i malé rozdíly od normality jsou statisticky významné. Proto pokud př́islušná skupina respondentů měla alespoň 10 členů, tak byl pro testování rozdílu mezi jednotlivými skupinami použit ve shodě $s$ poznatky Mareše a kol. (2015, s. 224-226) nejprve neparametrický Mannův-Whitneyův test a potom i parametrický T-test. Oba dospívali ke stejným závěrům. Následně tam, kde to mělo smysl, byla počítána síla účinku (Cohenovo $\mathrm{d}$ ), aby byl zjištěn věcný význam rozdílů.

\section{VÝSLEDKY}

\subsection{Rozdíly $\mathrm{v}$ aktivitách profes- ního rozvoje mezi jednotlivými skupinami učitelů}

Učitelé uváděli, že od června 2014 do června 2015 nejčastěji využívali (více než $70 \%$ z nich) ke svému rozvoji spíše jednodušší, ve školách běžné aktivity PRU, které nevyžadují spolupráci kolegů-učitelů, jako jsou např. (seřazeno od nejčastěji využívaných):

1. samostudium webových stránek, nerecenzovaných publikací a populárně naučných časopisů;

2. jednorázové jednodenní školení;

3. sebereflexe činnosti učitele;

4. metodická podpora $\mathrm{k}$ výuce předmětů nebo oborů (didaktické materiály).

Naopak aktivity, jež jsou často doporučované pro PRU, využívali učitelé řidčeji (maximálně $10 \%$ respondentů). Jedná se o tyto aktivity (seřazeno od nejméně využívaných):
1. videonahrávka a analýza výuky diskutovaná s kolegy-učiteli;

2. stínování učitele;

3. hospitační činnost učitele $\mathrm{v}$ jiné škole;

4. podpora supervizorem;

5. kolegiální hospitace kolegy z jiné školy;

6. poradenství od oborového didaktika z VŠ.

Míra využití jednotlivých aktivit podporujících PRU v uplynulém roce se u jednotlivých skupin učitelů lišila. Většinou se jedná o slabý vztah mezi aktivitou a konkrétní proměnnou. Statisticky významné se jeví především rozdíly mezi podsoubory strukturovanými dle typu školy. Jedná se o 18 aktivit z nabízených 32. Dále počet rozdílů mezi skupinami učitelů ovlivnil gender respondentů (u pěti aktivit) a délka pedagogické praxe (u tř́ aktivit).

Středně silná souvislost je mezi podporou začínajícím učitelům od uvádějících učitelů a délkou pedagogické praxe, kdy cca $50 \%$ učitelů $s$ praxí do pěti let využilo tuto aktivitu ke svému rozvoji. Spíše středně silná souvislost je mezi aktivitami: „podporou pedagogické činnosti od školního psychologa“ či „metodickou podporou $\mathrm{k}$ řešení konkrétních pedagogických problémü“ a typem školy učitele, kdy tyto aktivity využívali častěji učitelé ZŠ než jejich kolegové ze SŠ. Učitelé gymnázií a SOŠ využívali tyto aktivity řidčeji než jejich kolegové z ostatních škol. Zároveň je u slabá souvislost mezi těmito aktivitami a genderem, kdy učitelky-ženy využívají tyto podpory častěji než učitelé-muži. Spíše střredně silná souvislost je mezi podporou pedagogické činnosti od sociální- 
Tab. 2. Překážky profesního rozvoje učitelů

\begin{tabular}{|l|c|c|c|c|}
\hline & N & Průměr & SD & $\begin{array}{c}\text { Míra souhlasu } \\
\text { s výrokem (\%) }\end{array}$ \\
\hline Aktivity PRU kolidují s mým rozvrhem. & 1378 & 2,70 & 0,79 & 62 \\
\hline $\begin{array}{l}\text { Aktivity PRU jsou př́liš finančně náročné, } \\
\text { nemohu si je finančně dovolit. }\end{array}$ & 1382 & 2,42 & 0,84 & 45 \\
\hline $\begin{array}{l}\text { K účasti v aktivitách vedoucích k PRU nejsem } \\
\text { nijak motivován/a. }\end{array}$ & 1383 & 2,32 & 0,85 & 38 \\
\hline Nemám čas z důvodu rodinných povinností. & 1383 & 2,24 & 0,80 & 35 \\
\hline Neexistuje žádná vhodná nabídka aktivit PRU. & 1379 & 2,16 & 0,75 & 28 \\
\hline Zaměstnavatel PRU dostatečně nepodporuje. & 1380 & 2,04 & 0,86 & 25 \\
\hline $\begin{array}{l}\text { Nemám potřebné předpoklady (např. kvalifikaci, } \\
\text { zkušenosti, odpracované roky). }\end{array}$ & 1389 & 1,35 & 0,63 & 5 \\
\hline
\end{tabular}

ho pracovníka a typem školy učitele, kdy učitelé 2 . stupně $Z S ̌$ využívají tuto činnost častěji než ostatní učitelé. Naopak učitelé gymnázií a SOŠ využívají tuto aktivitu významně méně než ostatní učitelé.

$\mathrm{V}$ ostatních př́padech jsou mezi konkrétní uskutečněnou aktivitou a některou $\mathrm{z}$ proměnných slabé vztahy ${ }^{6}$ (viz tabulka $\mathrm{A} v$ př́loze).

\subsection{Rozdíly ve vnímání překážek profesního rozvoje mezi jednotli- vými skupinami učitelù}

Hlavní překážky realizace profesního rozvoje uváděné učiteli jsou shrnuty $\mathrm{v}$ tabulce 2 .

Přestože se jednalo $\mathrm{v}$ šetření TALIS 2013 v ČR o jinou skupinu učitelů, je pořadí překážek $\mathrm{k}$ PRU téměř totožné (srov. Kašparová et al., 2014b, s. 53-55).
Stručná odpověd' na druhou výzkumnou otázku by mohla být, že se jednotlivé skupiny učitelů odlišují ve vnímání překážek PRU v závislosti na věku a dalších proměnných (gender, druh a typ školy).

$\mathrm{V}$ grafech (obr. 1-6) jsou uvedeny průměrné hodnoty pro jednotlivé věkové kategorie učitelů, jak vnímali prŕslušnou přkkážku k PRU.

\section{Aktivity vedoucí k profesnímu rozvoji kolidují s rozvrhem}

Učitelé spíše souhlasí s tvrzením, že aktivity vedoucí $\mathrm{k}$ PRU kolidují s rozvrhem. Mezi učiteli ZŠ nejsou statisticky významné rozdíly. Pouze učitelky 2 . stupně ZŠ mladši 45 let významně častěji souhlasí s tvrzením, že aktivity vedoucí k PRU kolidují $s$ jejich rozvrhem, než jejich kolegyně starši 55 let (z hlediska významnosti jde o střední rozdíl) - viz obr. 1.

\footnotetext{
${ }^{6} \mathrm{U}$ typu školy je Cramerovo $\mathrm{V} v$ intervalu $\langle 0,10 ; 0,29\rangle$, u genderu je koeficient fí v absolutní hodnotě v intervalu $\langle 0,11 ; 0,17>$ a u délky pedagogické praxe se Cramerovo V pohybuje v intervalu $<0,11 ; 0,39>$.
} 


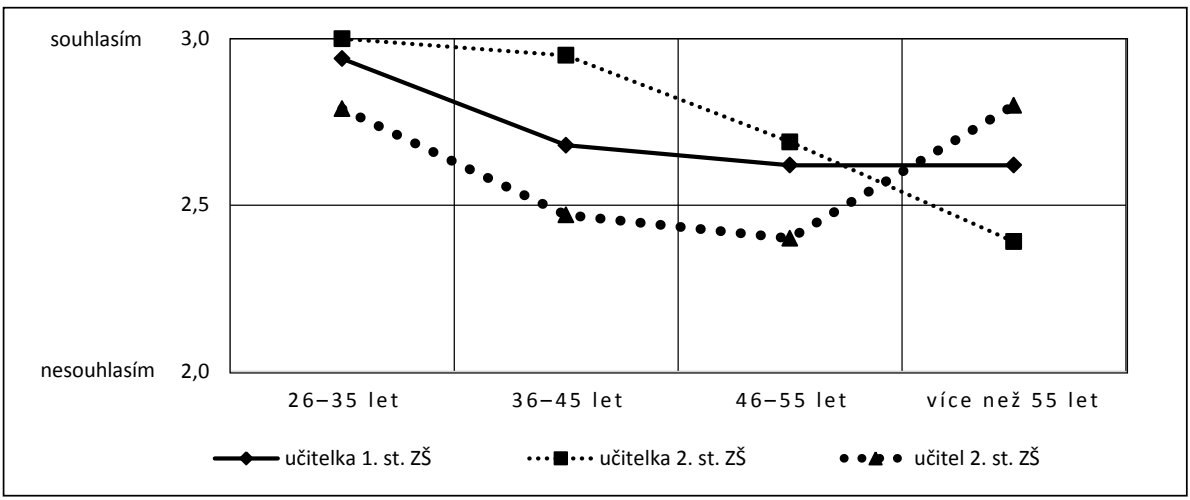

Obr. 1. Aktivity profesního rozvoje kolidují s mým rozvrhem - učitelé ZŠ

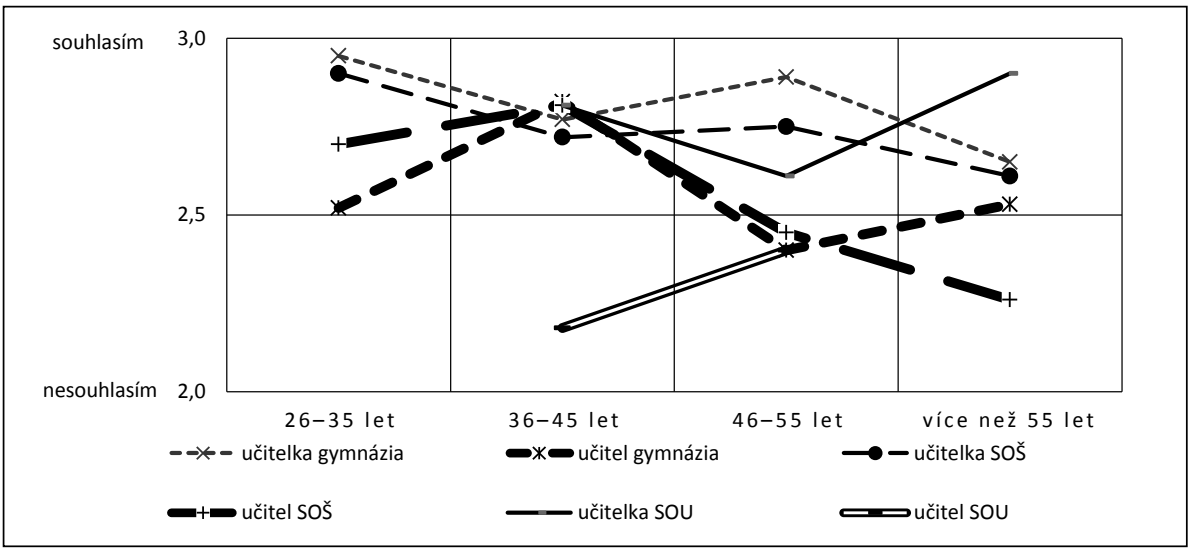

Obr. 2. Aktivity profesního rozvoje kolidují s mým rozvrhem - učitelé SŠ

Z hlediska významnosti je střední rozdíl mezi tím, jaký mají postoj $\mathrm{k}$ tomuto tvrzení učitelky gymnázia, SOŠ či SOU a učitelé SOU. Pro učitele SOU je kolize rozvrhu menší překážkou než pro učitelky gymnázií, SOŠ a SOU. Podobně je malý rozdíl ve vnímání mezi učitelkami a učiteli ze SOŠ, mezi učitelkami a učiteli z gymnázií či mezi uči- telkami SOU a učiteli SOŠ. Učitelky vnímají kolizi jako větší překážku než učitelé. Střední rozdíl je ve vnímání u učitelů SOŠ ve věkové kategorii 36-45 let a u jejich kolegů starších 55 let, kteří tolik nevnímají kolizi mezi aktivitami PRU a svým rozvrhem (obr. 2). Mezi ostatními skupinami nejsou statisticky významné rozdíly. 


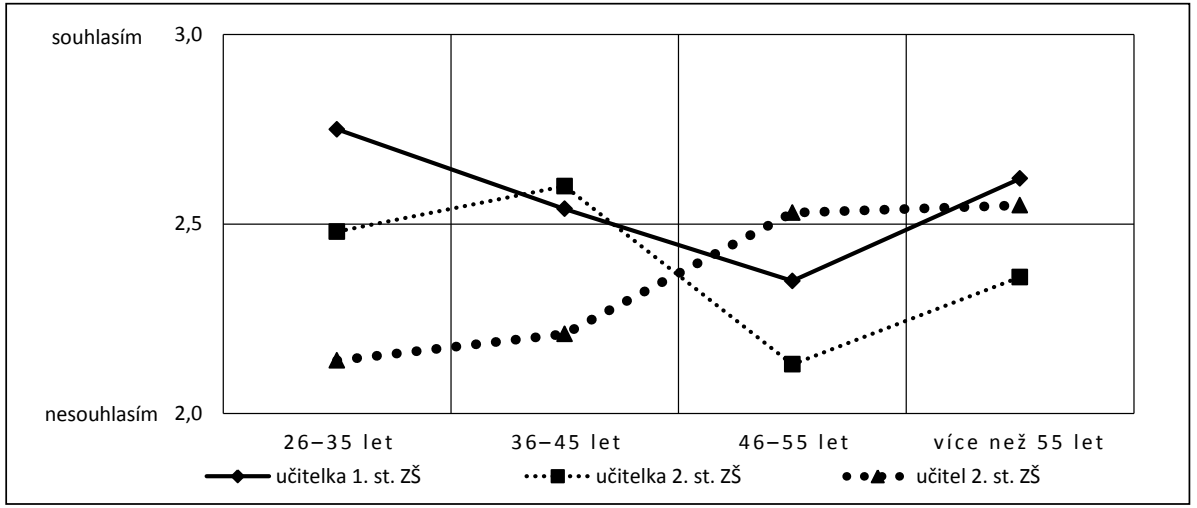

Obr. 3. Aktivity profesního rozvoje jsou př́liš finančně náročné, nemohu si je finančně dovolit učitelé $Z \check{S}$

Pokud nejsou učitelé rozděleni podle genderu, tak na základě typu školy mezi nimi nejsou statisticky významné rozdíly ve vnímání kolize aktivit PRU s jejich rozvrhem.

\section{Aktivity profesního rozvoje jsou př́liliš finančně náročné}

Učitelé ani nesouhlasí a ani souhlasí s tvrzením, že aktivity PRU jsou př́liš finančně náročné (nemohou si je finančně dovolit). Mezi učitelkami a učiteli ZŽ nejsou statisticky významné rozdíly. Pouze učitelky 2. stupně ZŠ ve věku 36-45 let považují aktivity vedoucí $\mathrm{k}$ PRU za finančně náročnější, než je tomu u jejich kolegyň ve věku 46-55 let (z hlediska významnosti jde o střední rozdíl) - viz obr. 3.

Pro učitele gymnázií (muže) aktivity PRU nejsou př́liš finančně náročné, jinak to hodnotí učitelky (ženy) ze SOŠ či SOU (z hlediska významnosti jde o malý rozdíl) - viz obr. 4. Jinak mezi učitelkami a učiteli SŠ nejsou statisticky významné rozdíly.

Pokud nejsou učitelé rozděleni podle genderu, tak pro učitele gymnázií aktivity PRU nejsou př́liš finančně náročné, jako to hodnotí učitelé 1 . stupně ZŠ a učitelé SOU (z hlediska významnosti jde o malý rozdíl). Jinak u tohoto výroku nejsou statisticky významné rozdíly ve vnímání učitelů Z $\check{S}$ a $S \check{S}$.

\section{Motivace k aktivitám vedoucím $k$ profesnímu rozvoji}

Učitelé spíše nesouhlasí s tvrzením, že k účasti $\mathrm{v}$ aktivitách vedoucích k PRU nejsou nijak motivováni (tab. 2). Z hlediska významnosti je malý rozdíl mezi tím, jaký mají postoj $\mathrm{k}$ tomuto tvrzení učitelky 1. stupně Ž̌, 2. stupně Ž̌s, gymnázií či SOŠ a mezi postoji učitelů gymnázií. Učitelé gymnázií jsou méně 


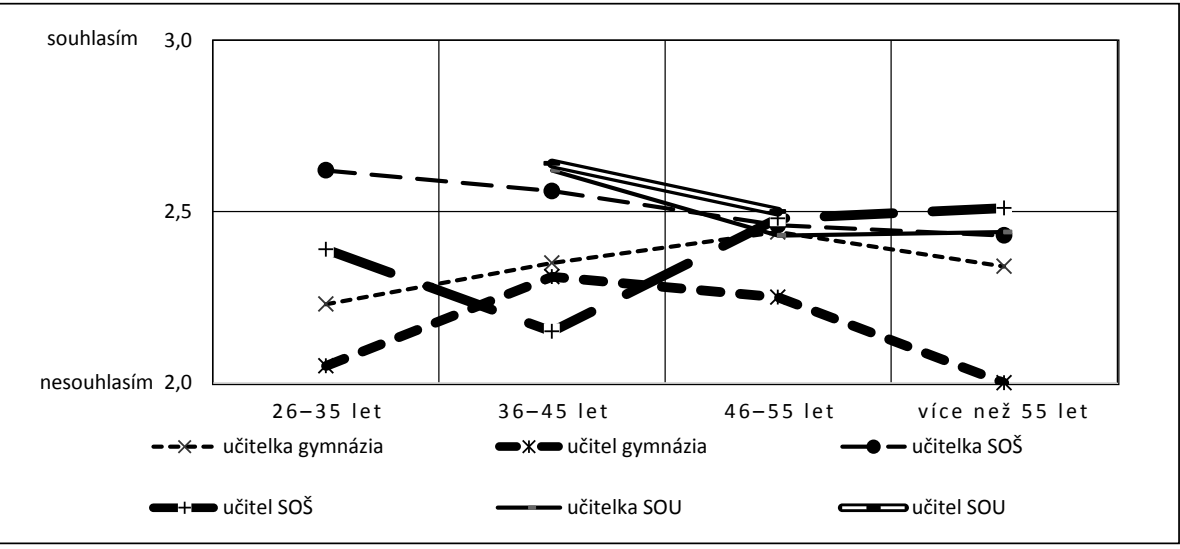

Obr. 4. Aktivity profesního rozvoje jsou př́liš̌ finančně náročné, nemohu si je finančně dovolit učitelé SŠ

motivovaní k PRU než zmiňované učitelky (obr. 5 a 6).

U učitelů 2. stupně ZŠ mladších 45 let je jejich motivace k PRU významně větší než u jejich kolegů starších 55 let (viz obr. 5). U ostatních věkových skupin a skupin učitelů nejsou statisticky významné rozdíly v motivaci k aktivitám PRU.

Pokud nejsou učitelé rozděleni podle genderu, z hlediska typu školy mezi nimi nejsou statisticky významné rozdíly v motivaci k aktivitám PRU.

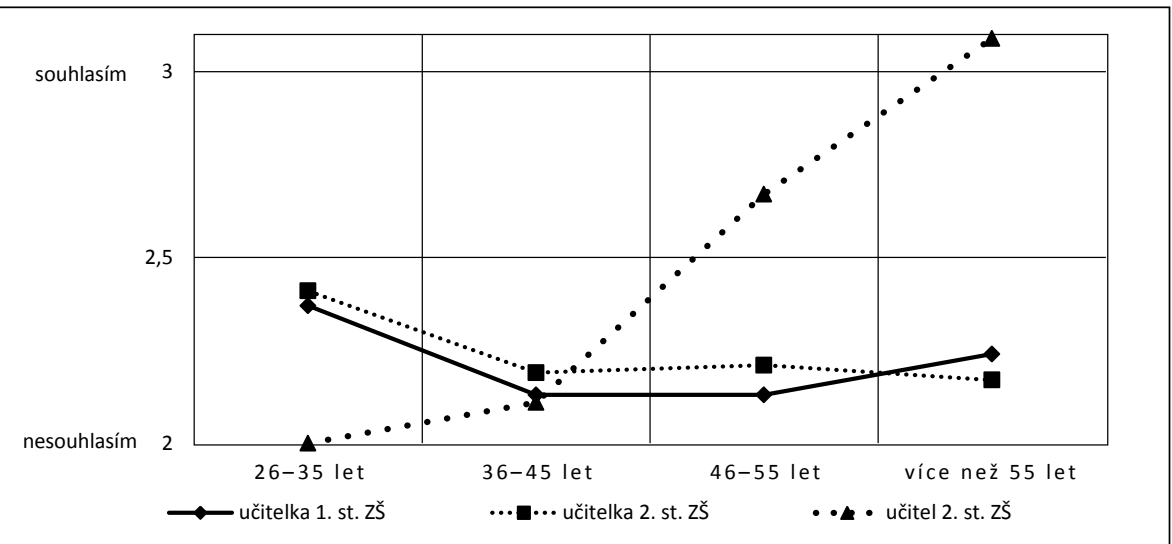

Obr. 5. K účasti v aktivitách vedoucích k profesnímu rozvoji nejsem nijak motivován/a - učitelé ZŠ 


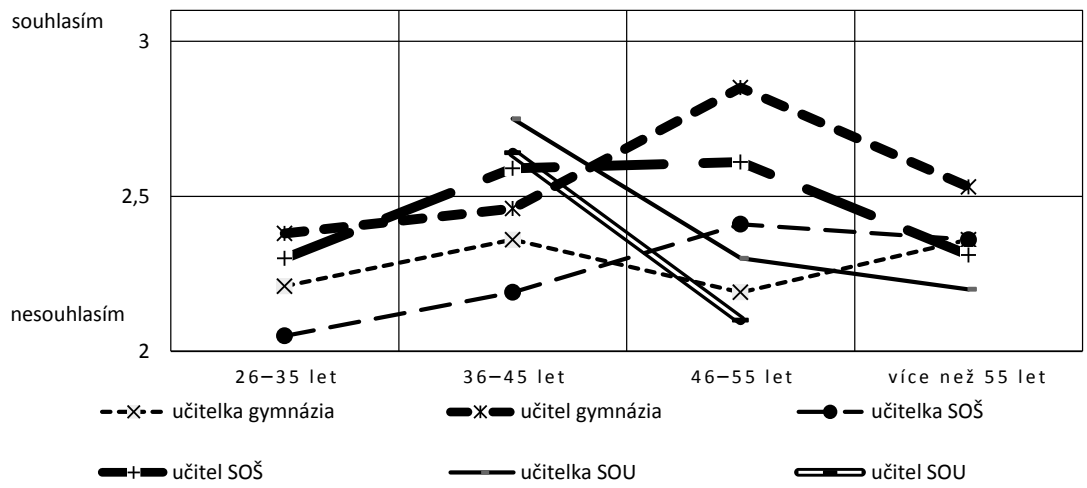

Obr. 6. K účasti v aktivitách vedoucích k profesnímu rozvoji nejsem nijak motivován/a - učitelé SŠ

\section{SHRNUTí, DISKUSE, ZÁVĚRY}

V tomto textu jsem si kladl za cíl představit podstatné výsledky z dotazníkového šetření NIDV z června 2015 zaměřeného na zjištění preferencí a odlišností různých skupin učitelů při zapojování se do aktivit PRU a jejich vnímání překážek PRU.

$\mathrm{K}$ uvedeným zjištěním je nutné přistupovat opatrně a s určitou skepsí. Jak je patrné z části 2.2, nejednalo se o soubor respondentů, který by měl reprezentativní charakter $\mathrm{k}$ zobecnitelné populaci učitelů ČR. Soubor respondentů neodpovídal očekávané struktuře respondentů podle kvalifikace, dosaženého nejvyššího vzdělání, věkové struktury, struktury učitelů v krajích a podle typů škol. Jednalo se o respondenty oslovené na základě jejich předchozího zájmu o vzdělávání u NIDV. Způsob výběru respondentů mohl vést ke zkreslení šetření, protože dotazník pro neznalost kontaktů neobdrželi učitelé, kteří se neúčastnili dalšího vzdělávání pedagogických pracovníků (DVPP). ${ }^{7}$ Zjištění také mohou být posunuta tím, že dotazník vyplnili respondenti motivovaní se jím zabývat. $Z$ hlediska návratnosti schází vyjádření od cca $84 \%$ oslovených učitelů, kteří dotazník nevyplnili. Ze získaných dat a z odpovědí na otevřené otázky dotazníků se lze domnívat, že dotazník vyplnili učitelé různých skupin. První jsou ti, kteří se věnují PRU a chtěli o tom poskytnout informaci. Druhou skupinu respondentů tvořili ti, kteří se sice zúčastnili nějaké vzdělávací aktivity NIDV, ale kteří mají kritický postoj k vzdělávací politice MŠMT, př́p. NIDV v oblasti PRU. Třetí skupinou mohli potom být učitelé, kteří obvykle splní „povinnost“ poskytnutí informací, pokud jsou požádáni státními institucemi.

${ }^{7} \mathrm{Cca} 40 \%$ všech učitelů ZŠ a SŠ se nikdy neúčastnilo DVPP pořádaného NIDV. 
Dalším limitem šetření je skutečnost, že nevíme, jak kvalitně zrealizované byly aktivity (co do obsahu a formy), které učitelé absolvovali. $\mathrm{Na}$ tento aspekt klade důraz Avalos (2011, s. 13), když hovoří o roli zprostředkovatelů, jak kvalitně podporují učení učitelů. $Z$ prezentovaných zjištění také nemáme informaci o rozsahu a prínosu aktivit PRU z hlediska př́nosů pro výsledky učení dětí, žáků a studentů. Nelze tak hodnotit účinnost aktivit PRU (např. Garet et al., 2001; Yoon et al., 2007; Vescio, Ross \& Adams, 2008). Další chybějící informací je neznalost lokálního kontextu, okolností, za nichž učitelé absolvovali některou aktivitu podporující PRU. Pro PRU může totiž platit to samé, co uvedli Wilson a Berne (1999, s. 174) pro další vzdělávání učitelů, kdy o něm píši jako o „spleti př́ležitostí - formálních a neformálních, povinných a dobrovolných, štastných náhodách a plánovaných aktivitách - spojených dohromady v roztřišstěné a nesouvislé kurikulum“. Nabízí se otázka, zda šlo u respondentů o roztř́išstěné a nesouvislé kurikulum, nebo zda byli cílevědomě a plánovitě vedeni při svém profesním rozvoji. PRU významně ovlivňuje způsob vedení učitelů, tj. jak nadřízení či zkušení učitelé (mentoři) uplatňují své manažerské dovednosti $\mathrm{k}$ učitelům (srov. Taylor et al., 2011).

V neposlední řadě je limitem šetření porozumění některým položkám dotazníku respondenty. Např́klad je otázkou, jak interpretovat skutečnost, že 22 učitelů s pedagogickou praxí delší než 36 let uvedlo, že v uplynulém roce využili ,podporu mně začínajícímu učiteli uvádějícím učitelem“. Tito učitelé určitě sebe nemohli chápat jako začínající. Byli tedy uvádějícím učitelem? Jaký by byl počet učitelů se shodnou délkou pedagogické praxe, kdyby položka zněla „Podpora mně, uvádějícího učitele, začínajícímu učiteli“? Nebo kladně odpověděli, protože si nevšimli věty „Využil/a jsem v posledních 12 měsících..." a vzpomněli si, že před více než 36 lety měli uvádějícího učitele?

I přes uvedené limity výzkumné šetření přineslo řadu zajímavých poznatků:

- Učitelé ZŠ a SŠ uváděli, že k PRU využívají častěji spíše jednodušší, ve školách běžné aktivity PRU, které nevyžadují spolupráci s jinými učiteli, netrvají delší časové období, částečně jsou diferencované podle individuálních potřeb jednotlivých učitelů a částečně zahrnují prvky aktivního učení. Řidčeji potom uváděli využívání aktivit PRU, u kterých učitelé vnímají, že zlepšují jejich znalosti a dovednosti a mají vliv na jejich praxi ve tř́ídě (Garet et al., 2001; OECD, 2013, s. 25-27).

- Jako nejčastější překážku k PRU uváděli učitelé ZŠ a SSS (v tomto pořadí): kolizi aktivit PRU s rozvrhem, dále finanční náročnost aktivit, nedostatek své motivace $\mathrm{k}$ účasti, rodinné povinnosti, neexistenci vhodné nabídky a nedostatek podpory od zaměstnavatele. Nejméně jim k aktivitám chyběly potřebné předpoklady (např. kvalifikace, zkušenosti).

Zajímavá jsou zjištění preferencí učitelů různých typů škol ve výběru aktivit podporujících PRU a vnímání překážek PRU. 
- Učitelé 1. stupně ZŠ k PRU častěji než ostatní využívají metodickou podporu, prijímají podporu od školního psychologa, využívají hodnotící rozhovor od nadřízeného, pracují s portfoliem, vyučují $\mathrm{v}$ tandemu, hospitují $\mathrm{v}$ jiné škole a mají hospitaci od kolegy z jiné školy. Naopak řidčeji než ostatní studují odborné recenzované texty, využívají podporu od předmětové komise, absolvují exkurze do neškolských organizací, získávají podporu od profesních asociací a navštěvují zahraniční školy.

Tito učitelé mají v průměru neutrální postoj k tvrzení, že aktivity PRU jsou př́liš finančně náročné. Oproti ostatním skupinám učitelů učitelky-ženy 1. stupně ZŠ jsou motivovanější $\mathrm{k}$ aktivitám PRU.

- Učitelé 2. stupně ZŠ k PRU častěji než ostatní využívají jednorázová školení, metodickou podporu, prijijimají podporu od školního psychologa a sociálního pracovníka, vyučují v tandemu a využívají mentoring.

Oproti ostatním skupinám učitelů učitelky-ženy 2. stupně Z $Z$ Ssou motivovanější k aktivitám PRU.

- Učitelé gymnázií k PRU častěji než ostatní navštěvují zahraniční školy. Naopak řidčeji než ostatní se účastní jednorázových školení, využívají metodickou podporu, príijímají hodnotící rozhovor od nadřízeného, pracují $s$ portfoliem, účastní se exkurzí, príijímají podporu od školního psychologa a sociálního pracovníka.

Tito učitelé v průměru spíše nesouhlasí $s$ tvrzením, že aktivity PRU jsou př́liš finančně náročné. $Z$ pohledu genderu silněji nesouhlasí oproti jiným skupinám s finanční náročností gymnaziální učitelé-muži. Dále učitelé-muži oproti ostatním skupinám učitelů jsou nejméně motivovaní $\mathrm{k}$ aktivitám PRU, nicméně jejich postoj je $\mathrm{v}$ průměru neutrální. Učitelky-ženy oproti ostatním skupinám učitelů hodnotí, že aktivity PRU kolidují s jejich rozvrhem.

- Učitelé SOŠ k PRU častěji než ostatní využívají podporu od předmětové komise, sami si studují odborné recenzované texty a účastní se exkurzí v neškolských organizacích. Naopak řidčeji než ostatní využívají metodickou podporu, podporu od školního psychologa a sociálního pracovníka, vyučují v tandemu, účastní se dlouhodobých vzdělávacích programů, hospitují v jiné škole a mají hospitaci od kolegy z jiné školy.

- Učitelé SOU k PRU častěji než ostatní uskutečnuuí exkurze do neškolských organizací a hospitují v jiné škole. Naopak řidčeji než ostatní využívají mentoring. Tito učitelé mají v průměru neutrální postoj k tvrzení, že aktivity PRU jsou př́liš finančně náročné. Nicméně učitelky-ženy na SOU vnímají u aktivit PRU finanční náročnost a kolizi se svým rozvrhem jako výraznější překážku oproti ostatním skupinám. Učitelé-muži na SOU naopak oproti učitelkám SOU a ostatním skupinám učitelů u aktivit PRU spíše nevnímají kolizi se svým rozvrhem.

Zjištěné odlišnosti zájmu různých skupin učitelů o aktivity PRU a vnímání překážek by měly zajímat aktéry vzdělá- 
vací politiky při zavádění plánovaného kariérního systému a při snaze o nabíd$\mathrm{ku}$ aktivit vedoucích $\mathrm{k}$ PRU, abychom $\mathrm{v}$ souladu $\mathrm{s}$ modelem uvedeným Yoon a kol. (2007, s. 4) dospívali přes zlepšení znalostí i dovedností učitelů a zkvalitnění výuky ke zlepšení výsledků učení žáků. Učitelům různých typů škol by měl být doporučován diferencovaný př́ístup založený na porozumění, co tito učitelé preferují a jaké jsou důvody jejich motivací. Lze např. předpokládat, že navrhované změny $\mathrm{v}$ důsledku novely zákona o pedagogických pracovnících, tj. práci s plány profesního rozvoje, využívání portfolia při atestačním řízení, využití specializovaných činností (např. koordinátor vlast- ního hodnocení), pravděpodobně spíše přijmou za své učitelé 1 . stupně $Z S ̌$, než tomu bude u střredoškolských učitelů, zejména z gymnázií. Proto by plánované intervence vzdělávací politiky měly vždy zohledňovat kontext typů škol, na nichž učitelé vzdělávají a vychovávají děti, žáky či studenty, aby mnohdy dobře myšlené záměry byly ze strany učitelů následně přijaty s porozuměním.

\section{PoděKování}

Poděkování patří respondentům, kteří vyplnili dotazník, a dále recenzentům a editorům tematického čísla, kteří napomohli zaostrrit pohled při prezentaci zjištění z výzkumného šetření.

\section{Literatura}

Avalos, B. (2011). Teacher professional development in Teaching and Teacher Education over ten years. Teaching and Teacher Education, 27, 10-20.

Factum Invenio (2009). Analýza prèedpokladĩ a vzdèlávacich potřeb pedagogických pracovniki pro zkvalitňování jejich pedagogické práce. Učitelé ZŠ a SŠ. Praha: MŠMT.

Garet, M. S., Porter, A. C., Desimone, L., Birman, B. F., \& Yoon, K. S. (2001). What makes professional development effective? Results from a national sample of teachers. American Educational Research Journal, 38(4), 915-945.

Kašparová, V., Boudová, S., Ševců, M., \& Soukup, P. (2014a). Národni zpráva šetření TALIS 2013. Praha: ČSI.

Kašparová, V., Holečková, A., Hučín, J., Janík, T., Najvar, P., Píšová, M., ... Ševců, M. (2014b). Analytická zpráva z šetření TALIS 2013. Praha: ČSI.

Kašparová, V., Potužníková, E., \& Janík, T. (2015). Subjektivně vnímaná zdatnost učitelů v kontextu jejich profesního vzdělávání: zjištění a výzvy z šetření TALIS 2013. Pedagogická orientace, 25(4), 528-556.

Mareš, J. (2009). Edukace založená na důkazech: inspirace pro pedagogický výzkum i školní praxi. Pedagogika, 59(3), 232-258.

Mareš, P., Rabušic, L., \& Soukup, P. (2015). Analýza sociálněvědnich dat (nejen) v SPSS. Brno: Masarykova univerzita.

McKinsey \& Company (2010). Klesajicí výsledky českého základniho a středního školstvi: fakta a řešení. Praha: McKinsey \& Company. 
OECD (1998). Staying ahead. In-service training and teacher professional development. Paris: OECD.

OECD (2009). Creating effective teaching and learning environments: First results from TALIS. Paris: OECD.

OECD (2013). Teaching and Learning International Survey (TALIS). Conceptual framework. Paris: OECD.

Rýdl, K. (2014). Vývoj standardizace profese učitele České republice - nekonečný př́iběh? Orbis scholae, 8(3), 9-21.

Scheerens, J. (Ed.) (2010). Teachers' professional development. Europe in international comparison: An analysis of teachers' professional development based on the OECD's Teaching and Learning International Survey (TALIS). Luxemburg, Office for Official Publication of the European Union.

Starý, K., Dvořák, D., Greger, D., \& Duschinská, K. (2012). Profesní rozvoj učitelů. Praha: Karolinum.

Taylor, M., Yates, A., Meyer, L. H., \& Kinsella, P. (2011). Teacher professional leadership in support of teacher professional development. Teaching and Teacher Education, 27, 85-94.

Vescio, V., Ross, D., \& Adams, A. (2008). A review of research on the impact of professional learning communities on teaching practice and student learning. Teaching and Teacher Education, 24, 80-91.

Wilson, S. M., \& Berne, J. (1999). Teacher learning and the acquisition of professional knowledge: An examination of research on contemporary professional development. Review of Research in Education, 24, 173-209.

Yoon, K. S., Duncan, T., Lee, S. W.-Y., Scarloss, B., \& Shapley, K. (2007). Reviewing the evidence on how teacher professional development affects student achievement. Washington, DC: U.S. Department of Education, Institute of Education Sciences, National Center for Education Evaluation and Regional Assistance, Regional Educational Laboratory Southwest.

Ing. Stanislav Michek, Ph.D.,

Univerzita Hradec Králové,Pedagogická fakulta; email: stanislav.michek@uhk.cz 


\section{Příloha}

$\mathrm{V}$ tabulce $\mathrm{A}$ jsou tučně uvedeny podíly souhlasných odpovědí $\mathrm{k}$ uskutečněné aktivitě podporující profesní rozvoj učitelů (PRU) u skupin učitelů, mezi kterými byly shledány statisticky významné rozdíly (na hladině významnosti 0,05 ) a u kterých byl zjištěn alespoň slabý vztah (hodnota míry asociace byla alespoň rovna či vyšší než 0,10$)$. U těchto aktivit jsou uvedeny také míry asociace.
Znaménkové schéma (počet znamének) potom naznačuje u vybraných skupin učitelů rozdíly mezi napozorovanými a očekávanými hodnotami v uskutečněné aktivitě PRU. ${ }^{8}$ Aktivity podporující PRU jsou v tabulce A seřazeny od nejčastěji vybraných učiteli $\mathrm{k}$ nejméně využívaným $\mathrm{v}$ předchozím roce. Kód u názvu aktivity PRU označuje prŕśslušnost aktivity $\mathrm{k}$ tematické oblasti a pořadí položky v dotazníku (viz podkap. 2.2).

Tabulka A. Rozdíly ve využití aktivit PRU v uplynulém roce mezi učiteli podle typu školy, na které učitelé působí; podíl souhlasných odpovědí z počtu respondentů skupiny učitelů uvedený v procentech.

\begin{tabular}{|c|c|c|c|c|c|c|}
\hline \multirow[b]{2}{*}{$\begin{array}{l}\text { Aktivity PRU uskutečněné } \\
\text { v uplynulém roce }\end{array}$} & \multicolumn{5}{|c|}{ Typ školy } & \multirow{2}{*}{$\begin{array}{l}\text { Crame- } \\
\text { rovo V }\end{array}$} \\
\hline & $\begin{array}{l}\text { 1. st. } \\
\text { ZSS }\end{array}$ & $\begin{array}{l}\text { 2. st. } \\
Z \check{S}\end{array}$ & G & SOŠ & SOU & \\
\hline $\begin{array}{l}7.29 \text { Samostudium webových stránek, } \\
\text { nerecenzovaných publikací a populár- } \\
\text { ně naučných časopisů }\end{array}$ & 88,4 & 94,9 & 92,3 & 93,7 & 88,8 & \\
\hline 1.1 Jednorázové jednodenní školení & 87,5 & $90,6^{++}$ & $77,7^{-}$ & 81,1 & 78,7 & 0,10 \\
\hline 4.16 Sebereflexe mé činnosti učitele & 73,6 & 82,0 & 84,0 & 81,3 & 80,9 & \\
\hline $\begin{array}{l}\text { 7.32 Metodická podpora k výuce } \\
\text { předmětů nebo oborů (didaktické } \\
\text { materiály) }\end{array}$ & $85,2^{+++}$ & $83,1^{+++}$ & $67,7^{--}$ & $71,1^{-}$ & 68,5 & 0,17 \\
\hline $\begin{array}{l}\text { 4.15 Rozvojový hodnoticí rozhovor } \\
\text { s kolegou na stejné úrovni }\end{array}$ & 72,7 & 69,8 & 62,9 & 65,8 & 57,3 & \\
\hline $\begin{array}{l}\text { 4.14 Hodnoticí rozhovor od nadří- } \\
\text { zeného }\end{array}$ & $69,4^{++}$ & 68,6 & $52,5^{-}$ & 62,3 & 60,7 & 0,14 \\
\hline $\begin{array}{l}7.30 \text { Samostudium odborných } \\
\text { recenzovaných publikací, sborníků } \\
\text { z pedagogických konferencí } \\
\text { a výzkumných zpráv }\end{array}$ & $49,5^{--}$ & 64,3 & 60,5 & $64,2^{+}$ & 65,2 & 0,11 \\
\hline
\end{tabular}

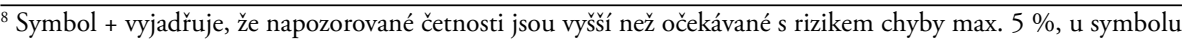
++ $s$ rizikem max. $1 \%$ a u symbolu +++ $s$ rizikem max. $0,1 \%$. Symbol - vyjadřuje situaci opačnou, tj. že napozorované četnosti jsou nižší než očekávané s rizikem chyby max. $5 \%$, u symbolu $--s$ rizikem max. $1 \%$ a u symbolu $---s$ rizikem max. $0,1 \%$.
} 


\begin{tabular}{|c|c|c|c|c|c|c|}
\hline \multirow[b]{2}{*}{$\begin{array}{l}\text { Aktivity PRU uskutečněné } \\
\text { v uplynulém roce }\end{array}$} & \multicolumn{5}{|c|}{ Typ školy } & \multirow{2}{*}{$\begin{array}{l}\text { Crame- } \\
\text { rovo V }\end{array}$} \\
\hline & $\begin{array}{l}\text { 1. st. } \\
\text { ZS }\end{array}$ & $\begin{array}{l}\text { 2. st. } \\
Z \check{S}\end{array}$ & G & SOŠ & SOU & \\
\hline $\begin{array}{l}\text { 3.9 Podpora pedagogické činnosti od } \\
\text { předmětové komise }\end{array}$ & $39,8^{--}$ & 61,2 & 62,3 & $65,0^{+++}$ & 52,8 & 0,16 \\
\hline $\begin{array}{l}2.4 \text { Hospitace od kolegy ze školy, na } \\
\text { které působím }\end{array}$ & 61,6 & 54,9 & 50,4 & 51,8 & 53,9 & \\
\hline $\begin{array}{l}4.18 \text { Využití práce s evaluačními } \\
\text { nástroji (např́íklad hodnocení učitelů } \\
\text { žáky, rodiči apod.) }\end{array}$ & 50,5 & 51,0 & 57,9 & 54,3 & 43,8 & \\
\hline $\begin{array}{l}\text { 7.31 Metodická podpora } \mathrm{k} \text { řešení } \\
\text { konkrétních pedagogických problémů }\end{array}$ & $66,7^{+++}$ & $67,1^{+++}$ & $36,8^{--}$ & $44,2-$ & 50,6 & 0,27 \\
\hline $\begin{array}{l}\text { 6.27 Exkurze v komerčních prosto- } \\
\text { rách či ve veřejných a neziskových } \\
\text { organizacích }\end{array}$ & $36,6^{--}$ & 51,8 & $42,1^{--}$ & $56,6^{+++}$ & $59,6^{+}$ & 0,17 \\
\hline $\begin{array}{l}5.21 \text { Pedagogické konference nebo } \\
\text { semináře (kde učitelé a/nebo výzkum- } \\
\text { ní pracovníci prezentují výsledky } \\
\text { výzkumů a probíhá diskuze na téma } \\
\text { vzdělávání) }\end{array}$ & 40,3 & 46,3 & 44,5 & 43,2 & 33,7 & \\
\hline $\begin{array}{l}3.10 \text { Podpora pedagogické činnosti } \\
\text { od školního psychologa, speciálního } \\
\text { pedagoga nebo sociálního pedagoga }\end{array}$ & $66,7^{+++}$ & $47,1^{++}$ & $27,0^{--}$ & $30,0^{--}$ & 32,6 & 0,29 \\
\hline 6.25 Exkurze v jiné škole & 40,7 & 41,6 & $30,0^{---}$ & 39,2 & 44,9 & 0,11 \\
\hline $\begin{array}{l}1.2 \text { Krátkodobý vzdělávací kurz, } \\
\text { workshop v rámci DVPP (do } 50 \\
\text { prezenčních hodin }=8 \text { dnů) }\end{array}$ & 34,3 & 34,9 & 36,5 & 35,4 & 21,3 & \\
\hline $\begin{array}{l}3.12 \text { Poradenství od zkušených kole- } \\
\text { gů z jiné školy }\end{array}$ & 35,2 & 36,9 & 29,1 & 31,9 & 32,6 & \\
\hline $\begin{array}{l}\text { 5.24 Výuka (pedagogická činnost) } \\
\text { v tandemu s jiným učitelem }\end{array}$ & $39,8^{+++}$ & $35,7^{+}$ & $22,8^{--}$ & 25,4 & 31,5 & 0,15 \\
\hline $\begin{array}{l}\text { 4.17 Využití práce s portfoliem } \\
\text { učitele }\end{array}$ & $30,1^{+}$ & 24,7 & $19,0^{-}$ & 25,8 & 33,7 & 0,10 \\
\hline $\begin{array}{l}\text { 5.19 Mentoring poskytnutý kom- } \\
\text { petentní a zkušenou osobou v rámci } \\
\text { formálně nastaveného systému práce } \\
\text { ve škole }\end{array}$ & 21,3 & $25,5^{+++}$ & $11,6^{-}$ & 16,6 & $10,1^{-}$ & 0,14 \\
\hline $\begin{array}{l}\text { 5.22 Podpora získaná členstvím } \\
\text { v profesní asociaci, skupině }\end{array}$ & $6,0^{--}$ & 18,8 & 19,6 & 17,8 & 18,0 & 0,12 \\
\hline
\end{tabular}




\begin{tabular}{|c|c|c|c|c|c|c|}
\hline \multirow[b]{2}{*}{$\begin{array}{l}\text { Aktivity PRU uskutečněné } \\
\text { v uplynulém roce }\end{array}$} & \multicolumn{5}{|c|}{ Typ školy } & \multirow{2}{*}{$\begin{array}{l}\text { Crame- } \\
\text { rovo } \mathrm{V}\end{array}$} \\
\hline & $\begin{array}{l}\text { 1. st. } \\
Z \check{S}\end{array}$ & $\begin{array}{l}\text { 2. st. } \\
\text { ZS }\end{array}$ & G & SOŠ & SOU & \\
\hline $\begin{array}{l}1.3 \text { Dlouhodobý vzdělávací program } \\
\text { v rámci DVPP (nad } 50 \text { prezenčních } \\
\text { hodin }=8 \text { dnů) }\end{array}$ & $21,8^{++}$ & 17,3 & 15,4 & $13,8^{-}$ & 20,2 & \\
\hline $\begin{array}{l}5.23 \text { Účast na výzkumu tématu, které } \\
\text { mne odborně zajímá }\end{array}$ & 12,0 & 20,0 & 13,9 & 16,4 & 19,1 & \\
\hline 6.28 Návštěva zahraniční školy & $5,1^{\cdots-}$ & 14,1 & $20,8^{++}$ & 16,8 & 14,6 & 0,14 \\
\hline $\begin{array}{l}3.11 \text { Podpora pedagogické činnosti } \\
\text { od sociálního pracovníka }\end{array}$ & 14,4 & $22,0^{+++}$ & $4,7^{--}$ & $7,6^{-}$ & 18,0 & 0,21 \\
\hline $\begin{array}{l}\text { 3. } 8 \text { Podpora mně, začínajícímu } \\
\text { učiteli, od uvádějícího učitele }\end{array}$ & $17,1^{+++}$ & 9,0 & 9,8 & 9,6 & 10,1 & 0,10 \\
\hline $\begin{array}{l}\text { 2.5 Kolegiální hospitace kolegy z jiné } \\
\text { školy }\end{array}$ & $16,7^{+++}$ & 12,2 & 8,3 & $7,5^{-}$ & 12,4 & 0,12 \\
\hline $\begin{array}{l}\text { 3.13 Poradenství od oborového } \\
\text { didaktika z vysoké školy }\end{array}$ & 11,1 & 9,4 & 8,6 & 10,5 & 14,6 & \\
\hline $\begin{array}{l}\text { 5.20 Supervize - podpora supervi- } \\
\text { zorem, který napomáhá reflektovat } \\
\text { vlastní práci a vztahy, nacházet nová } \\
\text { řešení problematických situací } \\
\text { v pomáhajících profesích }\end{array}$ & 11,1 & 12,5 & 6,5 & 9,6 & 10,1 & \\
\hline $\begin{array}{l}\text { 2.7 Moje hospitační činnost v jiné } \\
\text { skole }\end{array}$ & $16,2^{+++}$ & 11,4 & 8,6 & $5,2^{--}$ & $18,0^{+}$ & 0,16 \\
\hline $\begin{array}{l}\text { 6.26 Stínování učitele (za účelem } \\
\text { studia jeho každodenních pracovních } \\
\text { činností, sleduje se jeho pracovní pro- } \\
\text { středí, metody a postupy, učí se, jak } \\
\text { lze dané metody uplatňovat v praxi) }\end{array}$ & 6,9 & 7,8 & 4,5 & 7,8 & 7,9 & \\
\hline $\begin{array}{l}2.6 \text { Videonahrávka a analýza mé vý- } \\
\text { uky / pedagogické činnosti diskutova- } \\
\text { ná s kolegy-učiteli }\end{array}$ & 6,5 & 6,7 & 3,9 & 5,0 & 3,4 & \\
\hline Počet respondentů & 216 & 255 & 337 & 523 & 89 & \\
\hline
\end{tabular}


MICHEK, S. Use of activities supporting professional development and their perceived obstacles by teachers of primary and secondary schools

In relation with the results of an international survey TALIS 2013 with the aim of introducing career system and emphasis on the teachers' professional development are becoming increasingly important issues as they develop professionally current teachers in the Czech Republic, which they use activities that support their professional development, and where they see the obstacles of their professional development. The article presents the results of a questionnaire survey. The article has shown differences in preferences of teachers of primary and secondary schools in activities supporting the teachers' professional development. This difference depends on the type of school where they operate, gender and teachers' practice in the profession. Conflict with the schedule was major obstacle of professional development what was mentioned by teachers.

Keywords: teachers' professional development, obstacles of professional development, teachers. 